\title{
Undergraduate Students' Use of Metacognitive Strategies While Reading and the Relationship Between Strategy Use and Reading Comprehension Skills
}

\author{
Neslihan Köse ${ }^{1} \&$ Firdevs Güneş ${ }^{2}$ \\ ${ }^{1}$ School of Foreign Languages, Bartın University, Bartın, Turkey \\ ${ }^{2}$ Department of Educational Sciences, Ankara University, Ankara, Turkey \\ Correspondence: Neslihan Köse, School of Foreign Languages, Bartın University, Bartın, Turkey. E-mail: \\ neslihankose@bartin.edu.tr
}

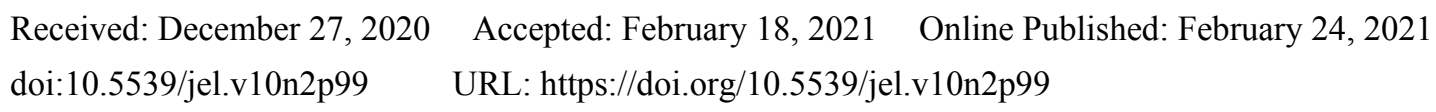

\begin{abstract}
Background: Lately in national and international reports, there has been an increasing interest on the significance of the development of reading skills. Countries are facing the problem of a decrease in reading habits (Niemann, 2016; Iyengar, 2007).
\end{abstract}

Method: This study examines the perceived use of metacognitive strategies among undergraduate students during reading, which encompasses the use of metacognitive strategies before, during and after reading. The sample group comprised 236 students at Primary Education (PE) and Social Studies Teaching (SST), Language \& Literature (LL) and Sociology departments during 2014-2015 academic year. The data were collected using the Metacognitive Awareness of Reading Strategies Inventory (MARSI) and reading comprehension achievement tests (informative and narrative).

Results: Overall strategy use among the sample group was "high". Whether there was a significant difference among students' perceived use of strategies in reading based on gender, grade, faculty and department was investigated. The results indicated a significant difference based on gender and grade level. Finally, it was found that as the reading comprehension increased in narrative texts, so did the strategy use in overall scale as well as in Global Reading Strategies and Problem Solving Strategies sub-scales.

Conclusion: The findings indicated gender differences in the use of reading strategies. It can be suggested that students be provided with reading strategies training that considers the gender differences in the use of metacognitive strategies in reading. In addition, based on the grade difference between freshmen and senior students, in favor of senior students and arising from including strategy use training in the curriculum, reading and learning strategies training could be provided for students during undergraduate education.

Keywords: reading comprehension, metacognitive strategies, gender differences, grade level

\section{Introduction}

Every decade, constantly changing demands leads to changes in the skills individuals are expected to have. In this process of continuous change, one thing central to policymakers is equipping people with the skills necessary to achieve their full potential, take part in interconnected global economy and ultimately, convert better jobs into better lives (OECD, 2014). The intense competition all around the world makes it a necessity for countries to invest in their human capital in order to keep their existence in the knowledge-based societies of the present day. The driving force of economies, today, is education. Because what societies need are not just numerate and literate clerks as in the wake of the Industrial Revolution (Billington, 2011) but individuals who are lifelong learners and who can adapt to the changing needs of the workforce and the society. The gateway to education involves developing reading skills, which is comprised of a process of finding, interpreting and evaluating information from a range of texts (OECD, 2013).

Reading is a basic life skill and a cornerstone leading to success throughout life (Anderson et al., 1985). There are many definitions for this key skill. Whilst it was once viewed merely looking at and decoding a written text, today it is defined as a multi-level mental process that contributes greatly to the development of the intellect 
(Bamberger, 1975) and which involves more than 30 cognitive and metacognitive processes (Randi, Grigorenko, \& Sternberg, 2005) necessitating the coordination of a number of different information and cognitive skills (Anderson et al., 1985; Cain, Oakhill, \& Bryant, 2004). Research has shown that good readers use strategies. Reading not only includes cognitive competencies such as decoding and knowing words but also metacognitive competencies, which encompass awareness and utilization of appropriate strategies while reading (OECD, 2013). Strategies, which are deliberate actions, have been referred to as reasoning, problem solving and metacognition (Paris, Lipson, \& Wixon, 1983). Strategic readers are distinguished from others by their ability to choose the right strategies while reading (Paris, Wasik, \& Turner, 1991). Metacognition, in the broadest sense, is defined as 'thinking about thinking'. The term metacognition has a multidimensional structure and involves an awareness of one's own thinking, awareness of the content, monitoring one's cognitive processes and regulating cognitive processes (Hennesey, 1999). John Flavell first coined the term and since then, there have been various groupings of the term metacognition. Basically, grouping can be given as knowledge of cognition and regulation of cognition. Knowledge of cognition involves declarative, procedural and conditional knowledge. Declarative knowledge is about what we know about our cognition, procedural knowledge is about how we practice what we know and conditional knowledge is about when and why to use appropriate cognitive resources (Pintrich, Wolters, \& Baxter, 2000, as cited in Whitebread \& Pasternak, 2010). Regulation of cognition, on the other hand, involves planning, monitoring and evaluation phases. The planning phase is about choosing the appropriate strategies, monitoring is one's awareness about whether he or she comprehends or not and evaluation is one's evaluation of the learning products and efficiency of his or her learning.

In short, strategic readers employ the right strategies to maximize comprehension and they plan, monitor and evaluate the process of reading.

\subsection{Theoretical Background and Relevant Literature}

Reading skills are essential for academic achievement. However, most students do not adequately develop this skill and have lower scores in reading comprehension tests compared to previous years (National Assessment of Educational Progress, 2019). Today, reading skill is not only essential for academic success (Clemens et al., 2020) but also a prerequisite for successful participation in areas of adult life (Rajchert, Zultak, \& Smulczyk, 2014). Literacy in all areas of life is the currency of modern societies and those with below-average skills cannot expect to earn above-average salaries in this global economy (OECD, 2010). For Kirsch, Jungeblut, Jenkins and Kolstad (1993), adults with low levels of literacy were less likely to be employed full time compared to their literate peers. Recent studies, however, indicate that the time spent for reading long-form texts has been diminishing. Twenge, Martin and Spitzberg (2019) looked into whether the use of legacy media increased or decreased by the increase in the use of digital media and found that adolescents spend less time with legacy media such as books and magazines. There was a significantly sharp decline in print media. While $33 \%$ of 10 th graders read newspapers almost daily in 1990 s, that rate was $2 \%$ by 2016 . The case in Turkey is no different. OECD's Programme for International Student Assessment (PISA) is carried out every three years. In 2009, the study focused on reading skills. Turkey's score in reading literacy was 464 (OECD, 2010), ranking it $39^{\text {th }}$ among all participating countries and $31^{\text {st }}$ among OECD countries. And in the latest assessment in 2018, although Turkey had shown an increase, Turkey's score in reading comprehension was still 466, below OECD average which was 487 (OECD, 2019).

A review of relevant literature indicates a relationship between reading skills and strategy use. In his study, Alqahtani (2019) investigated the relationship between metacognitive strategy use and reading proficiency among university students and concluded that there was a high correlation between metacognitive approaches used and reading comprehension.

In their study, Denton et al. (2015) looked into individual differences in adolescents' reading comprehension strategy use related to reading proficiency, grade level and gender. One thousand thirty-four students studying grades 7-12 participated in the study. The findings indicated that more skilled readers reported significantly higher use of strategies. Similarly, adolescent girls reported greater use of reading comprehension strategies compared to boys.

Similarly, in Cantrell and Carter's (2009) study, in which they investigated relationships among perceived use of academic reading strategies and reading achievement in age and gender among adolescents, it was found that good readers reported using global and problem-solving strategies more often compared to poor readers. Poor readers, on the other hand, used support strategies more often compared to good readers. Finally, girls reported using all reading strategies to a greater extent than boys.

In Alsamadani's (2009) study, in which he investigated the relationship between Saudi EFL college-level 
students' use of reading strategies and their EFL reading comprehension, he also analyzed gender differences among EFL Saudi students in terms of comprehension level and strategy use. The findings indicated that females reported using evaluation strategies to a greater extent when compared to males.

Dermitzaki, Andreou and Paraskeva (2008) investigated the strategic behaviors of high and low achievers in reading comprehension. A total number of 45 third graders ( 20 high achievers in reading comprehension and 25 low achievers) participated in the study. The results showed that high achievers employed higher strategic behaviors compared to low achievers.

Griva, Alevriadou and Semoglou (2012) investigated the correlation between gender and reading preferences and reading strategies employed by fifth and sixth grade students. The results indicated that the female students employed cognitive and metacognitive strategies at a significantly higher extent compared to males.

Considering the given significance of reading in all areas of life, the current study explored undergraduate students' use of metacognitive strategies during reading to determine if there was a difference by gender, grade level, department and faculty. The study addressed the following research questions:

1) What is the overall level of metacognitive awareness of reading strategy use among undergraduate students?

2) Does the metacognitive awareness of reading strategy use differ depending on the following:
a. Gender
b. Grade level
c. Department
d. Faculty

3) Is there a relationship between using metacognitive strategies and reading comprehension?

\section{Method}

\subsection{Participants}

The current study is a quantitative research in nature and survey method was used. As Creswell (2014) indicates, survey designs study a sample of the population to determine quantitative or numeric description of trends, attitudes or opinions of a population. By using the data collected from a sample, the researcher makes a generalization of the population. Accordingly, the present study conducted during the 2014-2015 academic year comprised a sample of 236 freshmen and senior students in the Primary Education (PE) and Social Studies Teaching (SST) departments of the Faculty of Education and Language \& Literature (LL), as well as Sociology departments from the Faculty of Arts \& Humanities. Of 236 participating students, 158 (66.9\%) were female and $78(33.1 \%)$ were male. In addition, 99 (41.9\%) of the students were studying at the Faculty of Education and 137 (58.1\%) were studying at the Faculty of Arts \& Humanities. Of all the participating students, $45(19 \%)$ were studying SST; 54 (22.9\%) were studying PE; 67 (28.4\%) were studying LL and 70 (29.7\%) were studying Sociology. Finally, $141(59.7 \%)$ of the participants were freshmen and $95(40.3 \%)$ were senior students. Details are given in Table 1.

Table 1. Study sample

\begin{tabular}{llll}
\hline Faculty & Department & Grade level & N \\
\hline Faculty of Education & Social Studies Teaching & 1 & 25 \\
& Social Studies Teaching & 4 & 20 \\
& Primary Education & 1 & 22 \\
& Primary Education & 4 & 32 \\
Faculty of Arts \& Humanities & Turkish Language \& Literature & 1 & 43 \\
& Turkish Language \& Literature & 4 & 24 \\
& Sociology & 1 & 51 \\
& Sociology & 4 & 19 \\
& TOTAL & & $\mathbf{2 3 6}$ \\
\hline
\end{tabular}

\subsection{Data Collection Instruments}

2.2.1 Metacognitive Awareness of Reading Strategies Inventory

Data were collected using the Metacognitive Awareness of Reading Strategies Inventory (MARSI) developed by 
Mokhtari and Reichard (2002) and adapted into Turkish by Öztürk (2012). The inventory is a five-point Likert scale in which 1 represents "I never or almost never do this" and 5 represents "I always or almost always do this." The scale has three sub-scales: Global Reading Strategies; Problem Solving Strategies; and Support Reading Strategies.

Explanatory and confirmatory factor analyses of the adapted Turkish scale were conducted to see the construct validity. The correlation between the Turkish and English versions of the inventory was found as 0.96 . The results of first and second confirmatory factor analyses (CFA) indicated that the Turkish version of the scale was consistent with the original version. Fit indices were reported as $\mathrm{sd}=397, \mathrm{p}=.00, \chi 2 / \mathrm{sd}=1.44$, RMSEA $=0.044$, $\mathrm{SRMR}=0.052, \mathrm{GFI}=0.86, \mathrm{AGFI}=0.85, \mathrm{CFI}=0.98, \mathrm{NFI}=0.94, \mathrm{IFI}=0.98$ and NNFI $=0.98$. The reliability values of the factors of the inventory were found to range between 0.76 and 0.85 .

Cronbach Alpha value for the overall inventory was $\alpha=.88$. Cronbach Alpha values for Global Reading Strategies, Support Reading Strategies and Problem-Solving Strategies sub-scales were $\alpha=0.78 ; \alpha=0.71$ and $\alpha$ $=0.72$, respectively. As for Pallant (2007), ideally, the Cronbach alpha coefficient of a scale should be above 0.7 Cronbach alpha values of the present study and Öztürk's study are shown in Table 2 below:

Table 2. Cronbach Alpha values

\begin{tabular}{lll}
\hline & Öztürk (2012) & Current Study \\
\hline Overall Scale & $\alpha=0.93$ & $\alpha=.88$ \\
Global Reading Strategies & $\alpha=0.85$ & $\alpha=.78$ \\
Support Reading Strategies & $\alpha=0.81$ & $\alpha=.71$ \\
Problem Solving Strategies & $\alpha=0.76$ & $\alpha=.72$ \\
\hline
\end{tabular}

\subsubsection{Reading Comprehension Achievement Test}

The second instruments used to collect data were two reading comprehension tests. Two types of texts were used: a narrative and an informative text. Each text had 10 open-ended reading comprehension questions. To confirm the content validity of the questions, they were sent to three academics in the field of language. Based on their reviews, no revisions were necessary. Both instruments were then piloted on different groups of students and three academics were asked to grade the questions. As a result, the questions were found to be reliable and administered to the relevant sample.

\subsection{Analysis of Data}

As MARSI is a five-point Likert scale in which 1 represents "I never or almost never do this" and 5 represents "I always or almost always do this." the collected data were graded between 1-5 and sticking to the original interpretation of the authors, 2.4 and lower scores were grouped under "low", 2.5 to 3.4 were grouped under "medium" and 3.5 or higher were grouped under "high" self-reported strategy use. Whether MARSI scores for the independent variables of the scale had a normal distribution was checked and the result of Kolmogorov Simirnov test revealed a normal distribution of variables $(p>0.05)$. Therefore, parametric test methods were chosen. In addition, students' scores from the reading comprehension achievement tests were calculated and Pearson product moment correlation coefficient was calculated to test the relationship between their reading comprehension achievement test and their metacognitive awareness levels in reading comprehension. Arithmetic averages and standard deviation values were calculated for the overall scale and sub-scale scores. And to identify whether there was a significant difference among students' perceived use of strategies in reading based on gender, grade, faculty and department, two-way analysis of variance (ANOVA) and multivariate analysis of variance (MANOA) were conducted.

\section{Findings}

\subsection{Findings on the First Research Question}

The first research question aimed at identifying the level of metacognitive awareness of reading strategy use. The results are presented in Table 3 below. 
Table 3. Descriptive statistics of MARSI scores

\begin{tabular}{llllll}
\hline & $\mathbf{N}$ & $\mathbf{X}$ & Sd & Min. & Max. \\
\hline Global Reading Strategies & 236 & 3.53 & .585 & 1.62 & 4.92 \\
Problem Solving Strategies & 236 & 3.87 & .609 & 1.63 & 5.00 \\
Support Reading Strategies & 236 & 3.53 & .670 & 1.11 & 5.00 \\
Overall Inventory & 236 & 3.57 & .531 & 1.83 & 4.83 \\
\hline
\end{tabular}

As is seen, student mean scores from Global Reading Strategies, Problem Solving Strategies, Support Reading Strategies and overall inventory were 3.53,3.87, 3.53 and 3.57, respectively. These findings indicate "high level" of strategy use as students' means in all categories was over 3.50.

\subsection{Findings on the Second Research Question}

The second research question guiding the current study was: "Does the metacognitive awareness of reading strategy use differ depending on gender, grade level, department and faculty?"

To test the impact of the independent variables gender, department, grade level and faculty on students' metacognitive awareness of reading strategy use, two-way analysis of variance (ANOVA) was performed. Homogeneity of variances and equality of variances were tested using Box' $M$ and Levene Test of Equality. The significance value was greater than 0.05 . Therefore, the assumption of homogeneity of variances was not violated and equality of variances was ensured. As faculty and department variables were related to each other, these two were separately included in the analysis. The results from ANOVA are presented in Table 4 below:

Table 4. ANOVA results on metacognitive awareness of reading strategy level depending on gender, faculty, department and grade level

\begin{tabular}{llllll}
\hline Source & (df) & Mean Square & $\boldsymbol{F}$ & Partial $\boldsymbol{\eta p ~ 2}$ & P \\
\hline Grade Level & 1 & 3.291 & 12.525 & .052 & $\mathbf{. 0 0 0 *}$ \\
Gender & 1 & 2.054 & 7.816 & .033 & $\mathbf{. 0 0 6}^{*}$ \\
Faculty & 1 & .046 & .176 & .001 & .675 \\
Department & 3 & .280 & 1.051 & .014 & .371 \\
Grade Level * Gender & 1 & .243 & .926 & .004 & .337 \\
Grade Level * Faculty & 1 & .561 & 2.135 & .009 & .145 \\
Gender * Faculty & 1 & .398 & 1.513 & .007 & .220 \\
Grade Level * Gender * Faculty & 1 & .004 & .016 & .000 & .900 \\
\hline
\end{tabular}

The results in Table 4 indicate a statistically significant main effect for gender $(\mathrm{p}<.05, \mathrm{~F}(1,228)=7.81$, $\mathrm{p}$ $=.006)$ and grade level $(\mathrm{p}<.05, \mathrm{~F}(1,228)=12.52, \mathrm{p}=.000)$, however, the effect size was small (partial eta squared $=.03)$. Looking at the mean scores for females, it is seen that girls' mean score $(M=3.63, S D=.50969)$ was significantly different from boys $(M=3.46, S D=.55994)$. Similarly, senior students' mean scores $(M=3.70$, $S D=.43138)$ were significantly different from freshman students $(M=3.49, S D=.57518)$. The results given in Table 4 indicate that the main effect for faculty and department was not statistically significant.

Multivariate analysis of variance (MANOVA) was performed to investigate under which sub-scales the use of metacognitive strategies while reading differ depending on gender, grade level and department. Three dependent variables (sub-scales of the inventory) were used: global reading strategies, problem solving strategies and support reading strategies. The independent variables were gender, grade level and department. The results are presented in Table 5.

Table 5. MANOVA results on MARSI sub-scales depending on gender, grade level and department

\begin{tabular}{lllllll}
\hline & Source & $(d f)$ & Mean Square & $\boldsymbol{F}$ & Partial $\boldsymbol{\eta p ~ 2 ~}$ & P \\
\hline Gender & Global Reading Strategies & 1 & 2.398 & 7.002 & .031 & $\mathbf{. 0 0 9}^{*}$ \\
& Problem Solving Strategies & 1 & 1.175 & 3.089 & .014 & .080 \\
Department & Support Reading Strategies & 1 & 4.480 & 10.687 & .046 & $.001 *$ \\
& Global Reading Strategies & 3 & .315 & .921 & .012 & .431 \\
Grade Level & Problem Solving Strategies & 3 & .071 & .186 & .003 & .906 \\
& Support Reading Strategies & 3 & .609 & 1.453 & .019 & .228 \\
& Global Reading Strategies & 1 & 3.415 & 9.974 & .043 & $\mathbf{. 0 0 2}^{*}$ \\
\hline
\end{tabular}




\begin{tabular}{lllllll}
\hline & Problem Solving Strategies & 1 & 1.174 & 3.087 & .014 & .080 \\
Gen.* Depart. & Support Reading Strategies & 1 & 4.259 & 10.161 & .044 &. $.002 *$ \\
& Global Reading Strategies & 3 & .267 & .781 & .011 & .506 \\
& Problem Solving Strategies & 3 & .084 & .222 & .003 & .881 \\
Gen.* Grade & Support Reading Strategies & 3 & .031 & .075 & .001 & .974 \\
& Global Reading Strategies & 1 & .512 & 1.495 & .007 & .223 \\
Depart. *Grade & Problem Solving Strategies & 1 & .050 & .131 & .001 & .718 \\
& Support Reading Strategies & 1 & 1.025 & 2.446 & .011 & .119 \\
Gen. *Dept. & Global Reading Strategies & 3 & .483 & 1.411 & .019 & .240 \\
*Grade & Problem Solving Strategies & 3 & .430 & 1.132 & .015 & .337 \\
& Support Reading Strategies & 3 & .355 & .848 & .011 & .469 \\
& Global Reading Strategies & 3 & .064 & .186 & .003 & .906 \\
\end{tabular}

In terms of gender, there was a statistically significant difference between boys and girls on Global Reading Strategies $(p<.05 . F(1,220)=7.00, p=.009$; partial eta squared $=.031)$ and Support Reading Strategies, $(p<.05 .(F(1,220)=10.6, p=.001$; partial eta squared $=.046)$. Looking at the mean scores, it is seen that girls' mean score under Global Reading Strategies $(M=3.59, S D=.58551)$ was significantly different from boys $(M=$ $3.45, S D=.62906)$. In Support Reading Strategies again, the girls' mean scores $(M=3.42, S D=.64562)$ were significantly different from boys' mean scores $(M=3.19, S D=.69615)$.

In terms of grade level, there was a statistically significant difference between freshman and senior students in Global Reading Strategies, $(p<.05 . F(1,220)=9.97, p=.002)$; partial eta squared $=.043)$ and Support Reading Strategies $(p<.05 .(F(1,220)=10.6, p=.001$; partial eta squared $=.044)$. Looking at the mean scores, it is seen that senior students' mean score under Global Reading Strategies $(M=3.70, S D=.52834)$ were significantly different from freshman students $(M=3.44, S D=.62936)$. Similarly, in Support Reading Strategies, it was again senior students' mean scores $(M=3.50, S D=.61323)$ that were significantly different from freshman students' scores $(M=3.24, S D=.68820)$.

Table 6 indicates a statistically significant difference in Global Reading Strategies and Support Reading Strategies in favour of girls and senior students. To find out which departments cause to this difference under these two sub-scales, MANOVA was repeated. Homogeneity of variances and equality of variances were tested using Box'M and Levene Test of Equality. The significance value was greater than 0.05 . Therefore, the assumption of homogeneity of variances was not violated and equality of variances was ensured. The results are presented in Table 6 below:

Table 6. The effect of gender and grade level in MARSI sub-scales depending on department

\begin{tabular}{|c|c|c|c|c|c|c|c|}
\hline Depart. & & Source & df & Mean squ. & $F$ & $\eta p 2$ & $\mathbf{P}$ \\
\hline \multirow[t]{9}{*}{ SS } & \multirow[t]{3}{*}{ Grade Level } & Global Reading Strategies & 1 & 2.330 & 5.868 & .125 & $.020 *$ \\
\hline & & Problem Solving Strategies & 1 & 1.588 & 3.831 & .085 & .057 \\
\hline & & Support Reading Strategies & 1 & 2.943 & 8.243 & .167 & $.006 *$ \\
\hline & \multirow[t]{3}{*}{ Gender } & Global Reading Strategies & 1 & .030 & .075 & .002 & .785 \\
\hline & & Problem Solving Strategies & 1 & .462 & 1.116 & .026 & .297 \\
\hline & & Support Reading Strategies & 1 & .574 & 1.607 & .038 & .212 \\
\hline & \multirow[t]{3}{*}{ Grade* Gender } & Global Reading Strategies & 1 & .188 & .473 & .011 & .495 \\
\hline & & Problem Solving Strategies & 1 & .292 & .704 & .017 & .406 \\
\hline & & Support Reading Strategies & 1 & .651 & 1.823 & .043 & .184 \\
\hline \multirow[t]{9}{*}{$\mathrm{PE}$} & \multirow[t]{3}{*}{ Grade Level } & Global Reading Strategies & 1 & 1.161 & 6.209 & .110 & $.016 *$ \\
\hline & & Problem Solving Strategies & 1 & .413 & 1.386 & .027 & .245 \\
\hline & & Support Reading Strategies & 1 & .955 & 2.796 & .053 & .101 \\
\hline & \multirow[t]{3}{*}{ Gender } & Global Reading Strategies & 1 & .863 & 4.613 & .084 & $.037 *$ \\
\hline & & Problem Solving Strategies & 1 & .373 & 1.252 & .024 & .269 \\
\hline & & Support Reading Strategies & 1 & 1.387 & 4.060 & .075 & $.049 *$ \\
\hline & \multirow[t]{3}{*}{ Grade* Gender } & Global Reading Strategies & 1 & .001 & .008 & .000 & .931 \\
\hline & & Problem Solving Strategies & 1 & .166 & .557 & .011 & .459 \\
\hline & & Support Reading Strategies & 1 & .369 & 1.080 & .021 & .304 \\
\hline \multirow[t]{2}{*}{ LL } & \multirow[t]{2}{*}{ Grade Level } & Global Reading Strategies & 1 & 1.498 & 3.005 & .046 & .088 \\
\hline & & Problem Solving Strategies & 1 & .257 & .552 & .008 & .347 \\
\hline
\end{tabular}




\begin{tabular}{|c|c|c|c|c|c|c|c|}
\hline \multirow{16}{*}{ Sociology } & \multirow{3}{*}{ Gender } & Support Reading Strategies & 1 & .552 & .898 & .014 & .473 \\
\hline & & Global Reading Strategies & 1 & 2.901 & 5.855 & .085 & $.018 *$ \\
\hline & & Problem Solving Strategies & 1 & .747 & 1.518 & .024 & .223 \\
\hline & \multirow{3}{*}{ Grade* Gender } & Support Reading Strategies & 1 & 1.916 & 3.114 & .047 & .082 \\
\hline & & Global Reading Strategies & 1 & .413 & .834 & .013 & .365 \\
\hline & & Problem Solving Strategies & 1 & .012 & .025 & .000 & .847 \\
\hline & \multirow{3}{*}{ Grade Level } & Support Reading Strategies & 1 & .023 & .038 & .001 & .876 \\
\hline & & Global Reading Strategies & 1 & .004 & .016 & .000 & .900 \\
\hline & & Problem Solving Strategies & 1 & .080 & .254 & .004 & .616 \\
\hline & \multirow{3}{*}{ Gender } & Support Reading Strategies & 1 & .382 & 1.160 & .017 & .285 \\
\hline & & Global Reading Strategies & 1 & .339 & 1.209 & .018 & .276 \\
\hline & & Problem Solving Strategies & 1 & .010 & .033 & .000 & .857 \\
\hline & \multirow{4}{*}{ Grade* Gender } & Support Reading Strategies & 1 & 1.091 & 3.313 & .048 & .073 \\
\hline & & Global Reading Strategies & 1 & .253 & .902 & .013 & .346 \\
\hline & & Problem Solving Strategies & 1 & .048 & .152 & .002 & .531 \\
\hline & & Support Reading Strategies & 1 & .131 & .397 & .006 & .698 \\
\hline
\end{tabular}

MANOVA was performed to investigate the source of gender and grade level difference under the two-sub-scales. It was found that females in PE reported higher levels of strategy use under "Global Reading trategies" and "Support Reading Strategies". Similarly, females in LL reported higher levels of strategy use under "Global Reading Strategies" sub-scale. On the other hand, senior students in SS reported higher levels of strategy use under "Global Reading Strategies" and "Support Reading Strategies" while senior students in PE reported higher levels of strategy use under "Global Reading Strategies" sub-scale.

\subsection{Findings on the Third Research Question}

The third research question aimed at finding out if there was a relationship between the use of metacognitive strategies and reading comprehension levels. The relationship between perceived use of metacognitive strategies (as measured by the MARSI) and reading comprehension (as measured by reading comprehension achievement tests) was investigated using Pearson product-moment correlation coefficient. The results of this analysis is presented in Table 7 below:

Table 7. Pearson product-moment correlations between perceived use of metacognitive strategies and reading comprehension

\begin{tabular}{llll}
\hline & & Narrative Text & Informative Text \\
\hline Overall Scale & Pearson Correlation & .176 & -.028 \\
Global Reading Strategies & $\mathrm{p}$ & $.007^{*}$ & .672 \\
& Pearson Correlation & .156 & -.037 \\
& $\mathrm{p}$ & $.016^{*}$ & .576 \\
Problem Solving Strategies & Pearson Correlation & .173 & .061 \\
& $\mathrm{p}$ & $.008^{*}$ & .348 \\
Support Reading Strategies & Pearson Correlation & .123 & -.075 \\
& $\mathrm{p}$ & .059 & .252 \\
\hline
\end{tabular}

The results of Pearson product-moment correlation indicate that as the scores from narrative text increase, so does the use of Global Reading Strategies and Problem Solving Strategies and overall strategy use. There was a weak positive correlation between scores from narrative text and above given strategy use $(r=.176, p<.05$ for Overall Scale; $\mathrm{r}=.156, \mathrm{p}<.05$ for Global Reading Strategies and $\mathrm{r}=.173, \mathrm{p}<.05$ for Problem Solving Strategies).

\section{Discussion}

The current study was designed to examine undergraduate students' use of metacognitive strategies during reading. To this end, the first research question guiding the study explored the metacognitive strategy using levels of the participating students and the results indicated that students' metacognitive strategy use was "high" in overall inventory and sub-scales. As strategy use is fundamentally related to development (Alexander et al., 1998), age is an important factor on strategy use (Cantrell \& Carter, 2009). Therefore, it is expected that higher education students have high level of strategy use.

The second research question aimed to explore whether metacognitive strategy use among students differed 
depending on gender, grade level, department and faculty students study at. The findings revealed that overall inventory scores showed a statistically significant difference in gender and grade level in favour of girls and senior students. The significant difference between girls and boys - in favour of girls - is seen in various national and international studies. In his study where he investigated whether there was a relationship between metacognitive strategy use and reading proficiency among university students, Alqahtani (2020) found girls' mean scores in strategy use were higher compared to boys in the study. Similarly, in her study in which she made a cross- gender comparison among college-level students in Oman, Alami (2016) found that girls' reported level of strategy use was higher than boys. In another study carried out to determine the level of metacognitive skills of undergraduate students at Hacettepe University, Altındağ (2008) found a statistically significant difference between girls and boys in favour of girls. In his study in which he looked into the relationship between metacognitive awareness and gender, Sarıçoban (2015) found that that there was a statistically significant difference between girls and boys in the "Declarative Information" dimension of the scale he used.

In Alsamadani's (2009) study, which was carried out to explore Saudi students' use of reading strategies and their effect on students' reading comprehension, differences favoring girls were found in overall strategy use, comprehension levels and the use of evaluating strategies. Lately, there has been a great deal of assessment, research and examination of the issue of boys' literacy attainment in various countries and although different schools have been implementing different strategies to improve the literacy attainment, girls continue to outperform boys on standardized assessment test and the gender gap remains (Booth, Elliott-Johns, \& Bruce, 2009). Although extensive research has been carried out for several years, this gender gap issue still remains as a major problem in the OECD countries with girl outperforming boys (Chuy \& Nitulescu, 2009). Similarly, in the PISA 2009 reading assessment, girls outperformed boys in every participating country by an average, among OECD countries, of 39 PISA score points - equivalent to more than half a proficiency level or one year of schooling. In 2015, though the gap narrowed in 32 participating countries, it still existed in 29 countries (OECD, 2016). Similarly, in the 2011 Progress in International Reading Literacy Study (PIRLS) report of International Association for the Evaluation of Educational Achievements (IEA), girls outperformed boys (Mullis, Martin, Foy, \& Drucker, 2012) in almost all of the countries.

Again, under the second research question, it was found that overall inventory scores showed a statistically significant difference in grade level favoring senior students. To put it in a different way, senior students use more strategies in reading than freshman students. To find out whether this was related to the course curriculum students are offered, the curriculum of the related departments was examined and it was seen that the grade level difference arises in SS and PE departments, where teaching towards the use of strategies is offered.

Similarly, in Denton et al.'s (2015) study of 1,100 students, found that students in upper grades reported using more strategies in different strategy groups compared to other students at lower grades. Within the scope of the second research question in which sub-scales of the inventory the difference in gender and grade level occurred was examined it was found that girls' strategy use was higher under Global Reading Strategies and Support Reading Strategies. In Mokhtari and Reichard's (2002) study in which they developed MARSI, they found that highly skilled readers used Global Reading Strategies and Problem Solving Strategies more often. In our case, girls used Global Reading Strategies and Support Reading Strategies more often. Similarly, a significant difference favoring senior students was found under Global Reading Strategies and Support Reading Strategies. Considering the items under the Global Reading Strategies sub-scale, it is possible to say that those highly skilled readers have a purpose in their minds when they read, they preview the text before they read, they think about what they know to help them understand the text, they decide what is important and what is not when they read and they critically analyze and evaluate the text when they read.

The third research question aimed at finding if there was a relationship between MARSI scores and reading comprehension scores from narrative and informative texts. The results of Pearson product-moment correlation indicate that as the scores from narrative text increase, so does the use of Global Reading Strategies and Problem Solving Strategies and overall strategy use. There was a weak positive correlation between scores from narrative text and above given strategy use. This finding aligns with Mokhtari and Reichard's (2002) study in which they developed MARSI. In their study, they indicate that skilled readers use Global Reading Strategies and Problem Solving Strategies more compared to those unskilled readers. However, in the current study there was no relationship between MARSI scores and reading comprehension scores from the informative text.

A review of relevant literature indicates that there are differences in the use of strategies among skilled and unskilled readers. Research indicates that skilled readers use strategies before, during and after reading. Skilled readers set a purpose before reading and plan the process; monitor comprehension while reading and use problem-solving strategies when they encounter comprehension problems; and check whether they met their 
purpose after reading (Cantrell \& Carter, 2009). In their study, Cantrell and Carter (2009) found a significant positive relationship between perceived use of global reading strategies and problem solving strategies and reading achievement. In other words, as reading achievement increases, so does students' use of global reading and problem solving strategies. Likewise, in their study in which they looked into the differences related to reading proficiency, grade level and gender, Denton et al. (2015) found that proficient readers used more strategies to combine what is given in the text with their background knowledge and to reach their reading objective.

\section{Acknowledgments}

Supported by the Bartın University Scientific Research Projects Commission (Project no: 2014-SOS-C-002).

\section{References}

Alami, M. (2016). Cross-gender comparison of metacognitive strategies utilized by Omani students in reading comprehension classes. International Journal of Applied Linguistics \& English Literature, 5(4), 20-28. https://doi.org/10.7575/aiac.ijalel.v.5n.4p.20

Alexander, P. A., Graham, S., \& Harris, K. R. (1998). A perspective on strategy research: Progress and prospects. Educational Psychology Review, 10, 129-154. https://doi.org/10.1023/A:1022185502996

Alqahtani, S. M. A. (2019). Investigating the relationship between metacognitive strategies and reading proficiency among the university students of Jeddah learners. Acra Scientiae et Intellectus, 5(4), 38-52.

Alsamadai, A. H. (2009). The Relationship between Saudi EFL College-Level Students'use of Reading Strategies and their EFL Reading Comprehension. Unpublished $\mathrm{PhD}$ dissertation. Ohio University. College of Education. Ohio.

Altındağ, M. (2008). Hacettepe Üniversitesi Eğitim Fakültesi Öğrecilerinin Yürütücü Biliş Becerileri. Unpublished PhD Dissertation. Hacettepe University, Graduate School of Social Sciences. Ankara.

Anderson, et al. (1985). Becoming a nation of readers. The report of the commission on reading. Retrieved from http://files.eric.ed.gov/fulltext/ED253865.pdf

Bamberger, R. (1975). Promoting the Reading Habit. Unesco.

Billington, R. (2011). Living Philosophy: An Introduction to Moral Thought. Routledge.

Booth, D., Elliott-Johns, S., \& Bruce, F. (2009). Boys' literacy attainment: Research and related practice. A report prepared for the Ontario Ministry of Education.

Cain, K., Oakhill, J., \& Bryant, P. (2004). Children's reading comprehension ability: Concurrent prediction by working memory verbal ability and component skills. Journal of Educational Psychology, 96, 31-42. https://doi.org/10.1037/0022-0663.96.1.31

Cantrell, S., \& Carter, J. (2009). Relationships among learner characteristics and adolescents' perceptions about reading strategy use. Reading Psychology, 30(3), 195-224. https://doi.org/10.1080/02702710802275397

Chuy, M., \& Nitulescu, R. (2009). Research Paper. PISA 2009. Explaining the Gender Gap in Reading through Reading Engagement and Approaches to Learning. Retrieved from http://www.cmec.ca/Publications/Lists/Publications/Attachments/302/PISA2009_Research_CMEC_HRSD C_EN.pdf

Clemens, N. H., Hsiao, Y., Lee, K., Martinez-Lincoln, A., Moore, C., Toste, J., \& Simmons, L. (2020). The differential importance of component skills on reading comprehension test performance among struggling adolescent readers. Journal of Learning Disabilities. https://doi.org/10.1177/0022219420932139

Creswell, W. J. (2014). Research Design. Qualitative, Quantitative and Mixed Method Approaches.

Denton, C. A., Wolters, C. A., York, M. J., Swanson, E., Kulesz, P. A., \& Francis, D. J. (2015). Adolescents' use of reading comprehension strategies: Differences related to reading proficiency, grade level, and gender. Learning and Individual Differences, 37, 81-95. https://doi.org/10.1016/j.lindif.2014.11.016

Dermitzaki, I., Andreou, G., \& Paraskeva, V. (2008). High and low reading comprehension achievers' strategic behaviors and their relation to performance in a reading comprehension situation. Reading Psychology, 29, 471-492. https://doi.org/10.1080/02702710802168519

Griva, E., Alevriadou, A., \& Semoglou, K. (2012). Reading preferences and strategies employed by primary school students: Gender, socio-cognitive and citizenship issues. International Education Studies, 5(2), 24-34. https://doi.org/10.5539/ies.v5n2p24 
Hennesey, M. G. (1999). Probing the Dimensions of Metacognition: Implications for Conceptual Change Teaching-Learning. Annual Meeting of the National Association for Research in Science Teaching. Retrieved from http://files.eric.ed.gov/fulltext/ED446921.pdf

Kirsch, I. S., Jungeblut, A., Jenkins, L., \& Kolstad, A. (1993). Adult literacy in America: A first look at the results of the National Adult Literacy Survey. Washington, DC: U.S. Department of Education.

Mokhtari, K., \& Reichard, C. A. (2002). Assessing students' metacognitive awareness of reading strategies. Journal of Educational Psychology, 94, 249-259. https://doi.org/10.1037//0022-0663.94.2.249

Mullis, I. V. S., Martin, M. O., Foy, P., \& Drucker, K. T. (2012). PIRLS 2011 international results in reading. Chestnut Hill, MA: TIMSS and PIRLS International Study Center, Boston College.

National Assessment of Educational Progress. (2019). The nation's report card: 2019 Reading national achievement level results. Retrieved from https://nces.ed.gov/nationsreportcard/

Niemann, J. R. (2016). Reading in the digital age. Retrieved from https://www.diva-portal.org/smash/get/diva2:1489099/FULLTEXT01.pdf

OECD. (2010). PISA 2009 Results: What Students Know and Can Do-Student Performance in Reading, Mathematics and Science (Volume I).

OECD. (2013). PISA 2015 Draft Reading Literacy Framework. Retrieved from http://www.oecd.org/pisa/pisaproducts/Draft\%20PISA\%202015\%20Reading\%20Framework\%20.pdf

OECD. (2014). PISA 2012 Results in Focus What 15-year-olds know and what they can do with what they know. Retrieved from https://www.oecd.org/pisa/keyfindings/pisa-2012-results-overview.pdf

OECD. (2016). Overview: Excellence and Equity in Education. In PISA 2015 Results (Volume I: Excellence and Equity in Education), OECD Publishing, Paris.

OECD. (2019). PISA 2018 Results (Volume I: What Students Know and Can Do). PISA, OECD Publishing, Paris. https://doi.org/10.1787/5f07c754-en

Öztürk, E. (2012). Okuma stratejileri üstbilişsel farkındalık envanterinin Türkçe formu'nun geçerlilik ve güvenirlik çalışması. Illkögretim Online, 11(2), 292-305.

Pallant, J. (2007). SPSS Survival Manual. A Step-by-Step Guide to Data Analysis Using SPSS for Windows (3rd ed.). New York: Mc Grow Hill.

Paris, S. G., Lipson, J. Y., \& Wixson, K. K. (1983). Becoming a strategic reader. Contemporary Educational Psychology, 8, 293-316. https://doi.org/10.1016/0361-476X(83)90018-8

Paris, S. G., Wasik, B. A., \& Turner, J. C. (1991). The Development of Strategic Readers. In R. Barr., M. L. Kamil, P. B. Mosenthal \& P. D. Pearson (Eds.), Handbook of Reading Research (Vol. 2, pp. 609-640). New York: Longman.

Rajchert, J. M., Żułtak, T., \& Smulczyk, M. (2014). Predicting reading literacy and its improvement in the Polish national extension of the PISA study: The role of intelligence, trait-and state-anxiety, socio-economic status and school-type. Learning and Individual Differences, 33, 1-11. https://doi.org/10.1016/j.lindif.2014.04.003

Randi, J., Grigorenko, E. L., \& Sternberg, R. J. (2005). Revisiting Definitions of Reading Comprehension: Just What is Reading Comprehension Anyway? In S. E. Israel, C. C. Block, K. L. Bauserman \& K. K. Welsch (Eds.), Metacognition in Literacy Learning (pp. 3-18). New Jersey: Lawrence Erlbaum Associates, Inc.

Twenge, J. M., Martin, G. N., \& Spitzberg, B. H. (2019). Trends in U.S. adolescents' media use, 1976-2016: The rise of digital media, the decline of TV, and the (near) demise of print. Psychology of Popular Media Culture, 8(4), 329-345. https://doi.org/10.1037/ppm0000203

Whitebread, D., \& Pino, P. D. (2010). Metacognition, Self-Regulation and Meta-Knowing (pp. 675-706). International Handbook of Psychology in Education.

\section{Copyrights}

Copyright for this article is retained by the author, with first publication rights granted to the journal.

This is an open-access article distributed under the terms and conditions of the Creative Commons Attribution license (http://creativecommons.org/licenses/by/4.0/). 